\title{
Stock Assessment of Lates niloticus in Upper Victoria Nile and its Impact on Uganda's Economy
}

\author{
Samuel Bassa ${ }^{1, *}$, Albert Getabu ${ }^{2}$, Eric O. Ogello ${ }^{3}$, A. M. Taabu ${ }^{4}$, D. O. Owiti ${ }^{3}$, Herbert \\ Nakiyende ${ }^{1}$, John Stephen Balirwa ${ }^{1}$, J. K. Nyaundi ${ }^{5}$, L. Musinguzi ${ }^{1}$, Winnie Nkalubo ${ }^{1}$ \\ ${ }^{1}$ National Fisheries Resources Research Institute. ${ }^{2}$ Department of Fisheries and Aquatic Studies, \\ Kisii University. ${ }^{3}$ Department of Fisheries and Natural Resources, Maseno University. ${ }^{4}$ Lake \\ Victoria Fisheries Organization. ${ }^{5}$ Kenya Marine Resources Research Institute. \\ *Corresponding author. (C)+256-772-648717 @ bassasam2018@gmail.com
}

\begin{abstract}
This study investigated the growth, mortality, recruitment, and catch estimates of Nile perch, Lates niloticus (Linnaeus, 1758), in Upper Victoria Nile, basing on total catches and lengthfrequency data collected between 2008 and 2018. The asymptotic length $\left(\mathrm{L}_{\infty}\right)$ had a value of 93.45 $\mathrm{cm}$ TL, growth curvature $(\mathrm{K})$ was 0.446 year $^{-1}$, total mortality $(\mathrm{Z})$ was 1.85 year $^{-1}$, natural mortality (M) was 0.79 year $^{-1}$, fishing mortality (F) was 1.09 year $^{-1}$, exploitation rate (E) was 0.59 and growth performance index $(Q)$ of $\left(\mathrm{L}_{\infty}\right)$ was 3.604. There were two peaks recruitment period, a minor one in March and a major one in August. These respectively accounted for 12.8 and 26.3 percent of the total catch. The optimum sustainable yield $\left(E_{0.5}\right)$, maximum sustainable yield $\left(E_{\max }\right)$ and, economic yield $\left(E_{0.1}\right)$ was $0.278,0.421$ and 0.355 respectively. The findings suggest that there is a decline in the population of Lates niloticus in Upper Victoria Nile. Therefore, strict management of the fishery by adhering to the recommended slot size of $50-85 \mathrm{~cm}$ TL and curtailing use of illegal gears is needed. This will be possible through enforcement of regulations, monitoring, control and surveillance in order to ensure sustainability of the Nile perch fishery and ecosystem restoration in the Upper Victoria Nile.
\end{abstract}

Keywords: Lates niloticus; Catch rates; Growth parameters, Upper Victoria Nile.

\section{Introduction}

Inland capture fisheries group activities that extract fish and other living organisms from the surface waters inland of the coastline. In 2008, inland capture fisheries produced an estimated 10 million tonnes of fish and crustaceans (Welcomme et al., 2010). Fish plays a role as a nutritional security and income to hundreds of million people in the rural household (Welcomme et al., 2010, Balirwa, 2007). In Africa, inland fisheries are utilised the same way like any other continent despite the fact that are characterized by patterns of overexploitation, environmental degradation and exotic species introduction (Balirwa, 2007). One of the major 
fish species that is highly utilised is the Lates niloticus, Nile perch. The Nile perch (Centropomidae: Lates niloticus L., 1758) was introduced in Lake Victoria in mid-1950s whose population exploration was realized in 1980s. By virtual of its proximity and flow the Nile perch was later on introduced into the Upper Victoria Nile (UVN). The main aim was to increase the economic value of the fishery that had been dominated with 500 -species of haplochromines cichlid flock (Anderson 1960; Ogutu-Ohwayo, 1990; Pringle, 2005; Balirwa, 2007). The increase in catches led to increased fish processing factories along the shores of Lake Victoria thus in turn resulting in rapid expansion of fishing effort and its overexploitation in the Lake Victoria basin (Okaranon et al., 1999; Balirwa, 2007).

Nile perch, like other fishes in the world is an important source of high quality proteins and a wide variety of essential micronutrients, trace minerals, vitamins and fatty acids (Kalhoro et al., 2017; Abowei et al., 2010). The species is an economically important commodity with various products and by-products such as the fillets, fish maws, fish oils, fish bones and skin that support many fisher communities in Uganda and the region at large. In spite of the decline attributed to overfishing due to the species high demand (Balirwa 2008; Ogutu-Ohwayo et al, 2013; Balirwa 2007; Yongo et al., 2018). However, with the new fishing regimes that included the use of lucrative illegal gears have led to the stock decline of the native fishery including the Nile perch from all lakes and the rivers. The decline of the Nile perch in the lakes has led the riparian people to exploit the riverine system including the upper Victoria Nile in order to meet the demand and supply.

Lates niloticus is a predator that breeds in littoral areas throughout the year with peaks during rainy seasons (Balirwa, 2000; Balirwa, 2008; Nkalubo et al., 2018). It is one of the species that has a high longevity ranging between 14-16 years as maximum age (Nkalubo 2012; Yongo et al., 2018) and almost occupying all the water depth levels in both lakes and rivers depending on how well the waters may be in terms of water parameters (Sitoki et al., 2011; Bassa et al., 2019). Because of the increased fishing effort, government has introduced strict measures to cattail overfishing and protects the breeding areas. The response has been informed by a number of findings from population structure and the stock assessment studies (Nkalubo et al., 2018) that have informed policy makers on the way forward. No effort however, has been made to assess the fishery, population structure and the stock assessment characteristics of the Nile perch in the UVN for further guidance on conservation and sustainable exploitation effort.

Studies have shown that fish growth, mortality and recruitment parameters are important for assessment and management of fish stocks population (Kalhoro et al., 2017; Abowei et al, 2010). This study utilised both total catches and length frequency data to determine the population structure, exploitation rate and fishing efforts of the Nile perch in UVN. The main aim was to assess the trends and fishing pressures of Nile perch in the UVN Bujagali area with a view of obtaining information to guide management for sustainable use and conservation of the species.

\section{Materials and Methods}

\section{Study Area}

The study was undertaken in the upper Victoria Nile, Bujagali stretch that comprise of Kalange area $\left(00.4748^{\circ} \mathrm{N}, 33.16634^{\circ} \mathrm{E}\right)$ to Buyala-Kikuba Mutwe $\left(00.50733^{\circ} \mathrm{N}, 33.13124{ }^{\circ} \mathrm{E}\right)$ north of the Equator (Figure 1). 


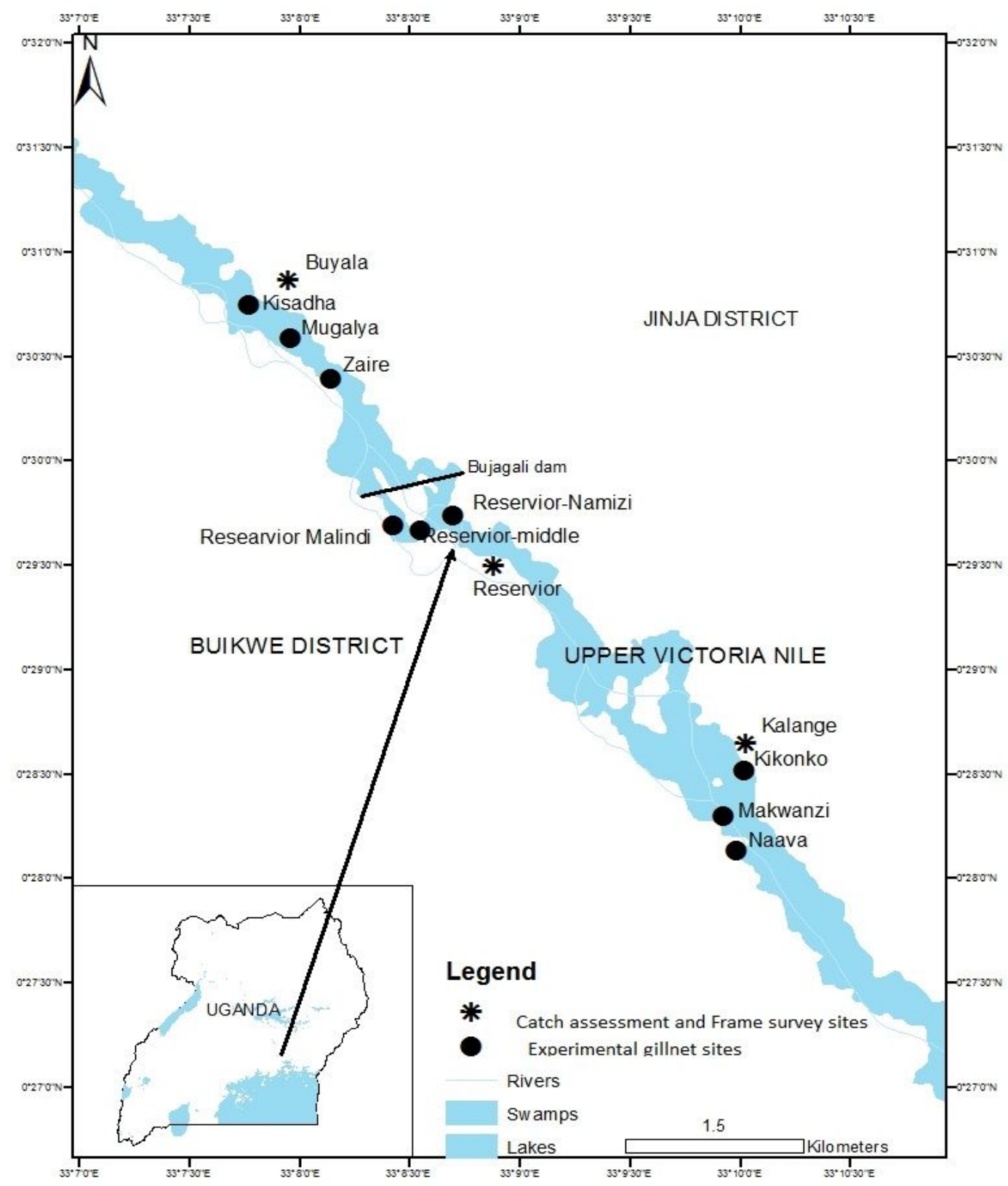

Figure 1: Study site.

The water temperature ranges between $23-26^{\circ} \mathrm{C}$ and the area receives mean annual rainfall of $1180 \pm 203 \mathrm{~mm}$. Natungoza et al., 2016, described the main geographical hydrological and physical characteristic of upper Nile in the Victoria basin. The sampled sites were twelve (12) in number; three for Catch assessment and Catch effort data collected on landing sites and nine for experimental gillnets set in the river (Figure 1). Site selection were done based on the following criteria:- i) Accessibility on either side of the bank of the river since not all areas were 
accessible due to the topography of the banks and very fast flow regime of the river. ii) Status of the fishing activities at the selected site. iii) Proximity upstream or downstream of the developmental projects like hydroelectric power site. iv) Coverage of a wide range of habitats. v) Representativeness of the upper Nile ecosystem.

Fish samples of Nile perch were collected from the upper Victoria Nile (UVN), Bujagali area bi-annual from 2008-2018. The sample sites were defined using a Garmin Satellite Navigator Global Positioning System (GPS) and depth (m) was estimated by an echo sounder.

\section{Length Weight Relationship}

The length weight relationship of the Nile perch was calculated by the power function. The length weight relationship of Nile perch fishes was calculated by the power function equation. $\mathrm{W}=\mathrm{aLb}$ where "W" is the total weight $(\mathrm{g})$, "L" is the total length $(\mathrm{cm})$, "a" is the intercept and "b" is the slope. The FISAT II was applied from data analysis (Gayanalo and Pauly, 1997). The length-weight relationships were estimated from the formula, $\mathrm{W}=\mathrm{aL}^{\mathrm{b}}$ where: $\mathrm{W}$ is the total body weight $(\mathrm{g}), \mathrm{L}$ is the total length $\mathrm{cm})$, $\mathrm{a}$ and $\mathrm{b}$ are coefficients of the functional regression between W and L (Bassa et al., 2018; Kalhoro et al., 2013; Nkalubo, 2012),

\section{Catch Rate Estimates, Size Structure, and Size at First Maturity}

Catch assessment datasets were used estimate to total annual landings, percentage composition by species, catch rates and average cost of each fish species per kilogram weight. The Catch per unit of effort was estimated. The average of values of fish per kilogram was computed over on annual basis to establish changes in annual estimates. Annual trends of total landings and catch per unit of effort were plotted using excel spreadsheet program. The size structure (length frequency) for the Nile perch, Lates niloticus, were plotted and represented in the results .Then subjected to statistical tests of by using ANOVA. Fish Catches was estimated by a procedure by Lake Victoria Fisheries Standard Operating Procedures (LVFO-SOPs 2007b).

The length at $50 \%\left(\mathrm{~L}_{50}\right)$ of the Nile perch in a class size in a class size were sexually mature was estimated from the ratio of the coefficients of a binary logistic regression of length and maturity level. These coefficients ( $\alpha$ and $\beta$ ) of the binary regression were estimated by Excelsolver statistical program in Excel micro software (Windows 7 professional). The length L50 $=$ Alpha $(\alpha) /$ Beta $(\beta)$, where $\alpha$ and $\beta$ are the coefficients of a two-parameter non-linear model (Aruho et al., 2018; Bassa et al., 2018; Nkalubo, 2012) obtained by stabilizing the coefficients and fitting the logistic ogive curve using Excel-solver. The two-parameter logistic ogive was described by the non-linear equation: $\mathrm{PL}=1 /\left[1+\exp ^{(\alpha-\beta L)}\right]$; Where PL is the predicted proportion of mature fish at length of the fish $\mathrm{L}, \alpha$ and $\beta$ were coefficients of the parameter model. All individuals in developing phase (stage II) and above (stages III, IV, V, VI, and VII) were taken as mature individuals (Brown-Peterson et al., 2011, Aruho et al., 2018). A regression between length and weight was run using Excel Microsoft to predict the corresponding weight at $\mathrm{L}_{50}$ for TL (cm). Comparisons of coefficient $\mathrm{b}$ of power equations obtained were based on Froese (2006). To obtain the size frequency distributions (number of sampled fish in each size class) for each size class for the collected data from each lake, individual sizes of fish were grouped in intervals of 2 units using a pivot table in Microsoft Excel. The graphs of Nile perch sizes were plotted against the class intervals obtained. 


\section{Growth Parameters}

Asymptotic length $\left(\mathrm{L}_{\infty}\right)$ and growth coefficient $(\mathrm{K})$ of the von Bertalanffy equation for growth in length of $\mathrm{L}_{\mathrm{t}}=\mathrm{L}_{\infty}\left(1-\operatorname{expK}\left(\mathrm{t}_{\mathrm{o}}-\mathrm{t}_{1}\right)\right.$ were estimated by means of ELEFAN (Pauly and Morgan, 1987). The $t_{0}$ value was estimated using the empirical equation; $\log _{10}\left(-t_{0}\right)=-0.3922-$ 0.2752 $\log _{10} \mathrm{~L}_{\infty}-1.038 \log _{10} \mathrm{~K}$ (Sparre and Venema, 1998, Yongo et al., 2018; Bassa et al., 2018). Then the growth performance of the Nile perch population in terms of length was compared as: $\mathrm{O}=\log _{10} \mathrm{k}+2 \log _{10} \mathrm{~L}_{\infty}$ (Sparre and Venema, 1998). Maximum age ( $\mathrm{t}_{\max }$ ) was estimated as $\mathrm{t}_{\max }=3 / \mathrm{k}+\mathrm{t}_{\mathrm{o}}$ (Sparre and Venema, 1998, Yongo et al., 2018)

\section{Mortality Rates and Recruitments}

The Natural mortality $(M)$ was estimated by Pauly empirical formula where by $\ln \mathrm{M}=(0.0152$ $\left.-0.279 * \ln \mathrm{L}_{\infty}+0.6543 * \ln \mathrm{K}+0.463 * \ln \mathrm{T}\right)$. Where $\mathrm{L}_{\infty}$ is the length at infinity, $\mathrm{K}$ is growth $\mathrm{O}$ constant and $\mathrm{T}$ is the mean temperature of the water body at $26^{\circ} \mathrm{C}$. Fishing mortality $(\mathrm{F})$ was obtained by subtracting $\mathrm{M}$ and $\mathrm{Z}$ and exploitation rate $(\mathrm{E})$ was estimated from $\mathrm{F} / \mathrm{Z}$. Total mortality ( $Z$ ) was estimated using length converted catch curve method as implemented in ELEFAN II (Sparre and Venema, 1998; Yongo et al.,2018; Bassa et al., 2018).

Estimation of the relative yield-per-recruit was done basing on Beverton and Holt (1966) model but modified by Pauly and Soriano (1986). The options assuming knife-edge selection was utilized, using probabilities of capture $L_{c} / L_{\infty}$ and $M / K$ ratios as inputs. Relative yield-perrecruit $\left(Y^{\prime} / R\right)$ was computed from the relationship:

$$
\frac{Y^{\prime}}{R}=E U^{M / k}\left\langle 1-\frac{3 U}{(1+m)}\left|\frac{3 U^{2}}{(1+2 m)}\right| \frac{3 U^{3}}{(1+3 m)}\right\rangle
$$

Where $\mathrm{U}=1-\left(\mathrm{L}_{\mathrm{c}} / \mathrm{L}_{\infty}\right) ; \mathrm{M}(1-\mathrm{E}) /(\mathrm{M} / \mathrm{K})=(\mathrm{K} / \mathrm{Z})$; and $\mathrm{E}=\mathrm{F} / \mathrm{Z}$.

Relative biomass per recruit $\left(\mathrm{B}^{\prime} / \mathrm{R}\right)$ was estimated from the relationship:

$$
\frac{B^{\prime}}{R}=\frac{\left(\frac{y}{R}\right)}{f}
$$

While $\mathrm{E}_{\max }, \mathrm{E}_{0.1}$ and $\mathrm{E}_{0.5}$ were estimated using the first derivative of this function, $\mathrm{E}_{\max }$ is the exploitation rate at maximum sustainable yield (MSY), $\mathrm{E}_{0.1}$ is the rate at maximum economic yield (MEY), and $\mathrm{E}_{0.5}$ is the optimum exploitation rate (Sparre and Venema 1998; Yongo et al., 2018; Njiru et al., 2008; Bassa et al., 2018; Kalhoro et al., 2013)

\section{Food, Feeding Interactions and Sex Ratios}

Samples from the stomach of Nile perch were analysed. The food content (prey taxa) was grouped, based on the length class of the Nile perch. Then later calculated in terms of relative abundance and percentage frequency. The food types were later subjected to chi-squire test to determine significance differences. The statistical tests were performed with SPSS 20.0 for Windows 7 professional.

Then differences in sex ratios of Nile perch from the UVN was estimated by use of a chisquire method to determine if the ratios were significantly different from the hypothetical 1:1 female to male ratio (Aruho et al 2018, Bassa et al. 2018). 


\section{Results}

The length and weight of Nile perch ranged from 12 to $89 \mathrm{~cm}$ (TL) total length, and in gram weight of 20.15 to 9,158 (Figures $3 \mathrm{a}$ ). The average length and weight is $50.5 \pm 2.6 \mathrm{~cm}$ TL and $2,636 \pm 302.8 \mathrm{~g}$ (TW) respectively. The length-weight relationship was calculated $\mathrm{W}=\ln \mathrm{q}+\mathrm{b}(\ln \mathrm{L}) ; \mathrm{W}=0.0102 \mathrm{~L}^{3.0539}\left(\mathrm{R}^{2}=0.984\right) ., \mathrm{n}=1,248$ (Figure3a). The catch rates varied from

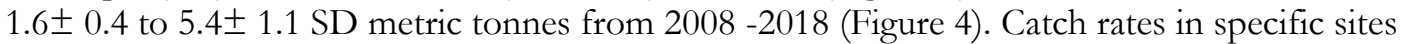
varied between 3 to $3.5 \mathrm{~kg} /$ boat/day. Catches were low in Kalange site compared to other sites throughout the sampling period (Figures 2a). Significant difference were noted between sampling sites using the Anova test that indicted $(\mathrm{F}=2.110 ; \mathrm{P}<0.05)$ in terms of catch rates. The correlation matrix of person square indicated the value of coefficient $\mathrm{r}$ of 0.822 at *. Correlation is significant at the 0.05 level (2-tailed). The highest peaks of annual catches recorded in 2017 at $81.08 \pm 3.79$, meanwhile low catches were observed in 2009 with $12.93 \pm 2.5$ tonnes (Figure $2 \mathrm{~b})$.
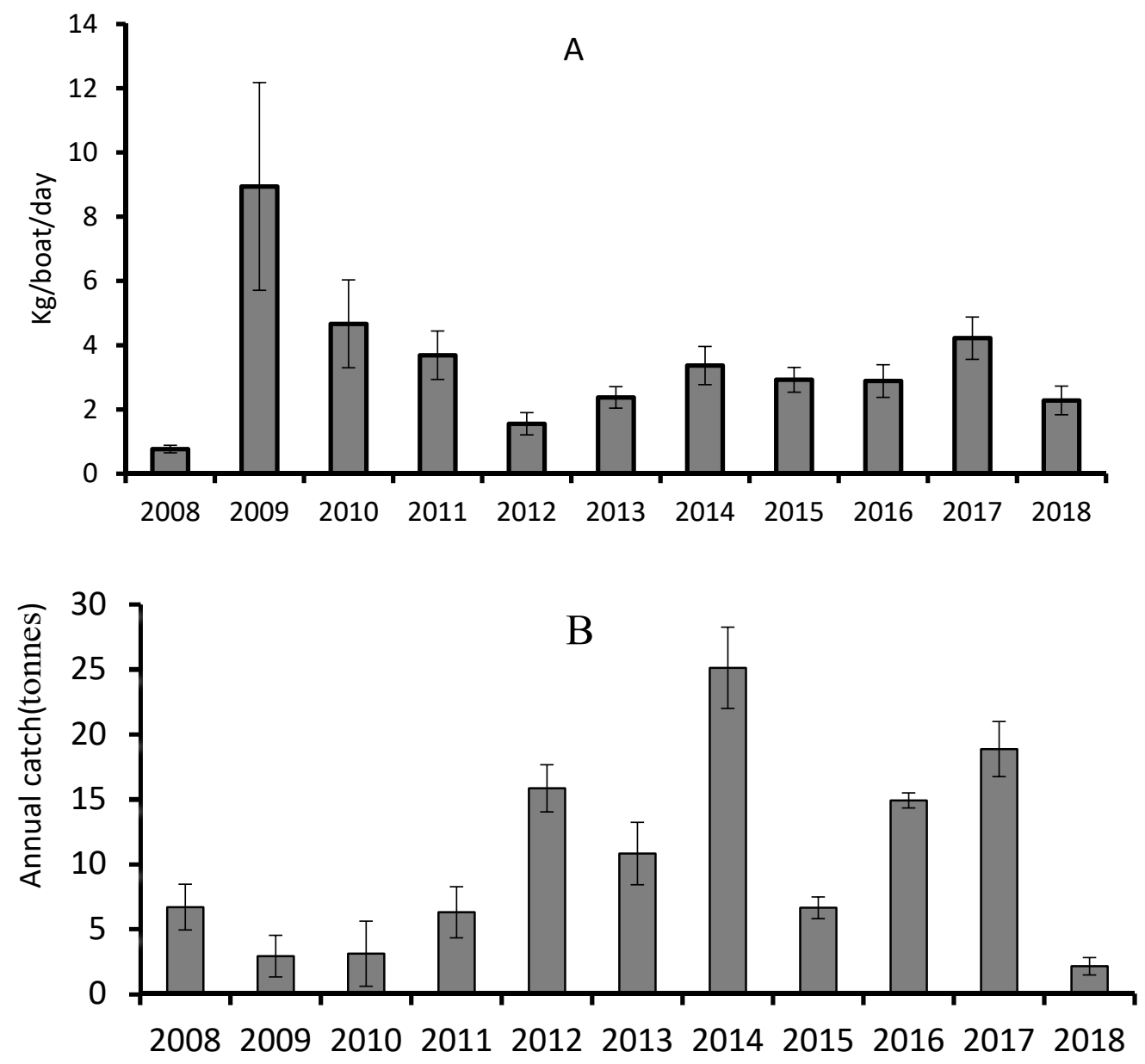

Figure 2. Catch Assessment for Lates niloticus along the Upper Victoria Nile (2008 to 2018) A) catch mean values, B) annual catches 

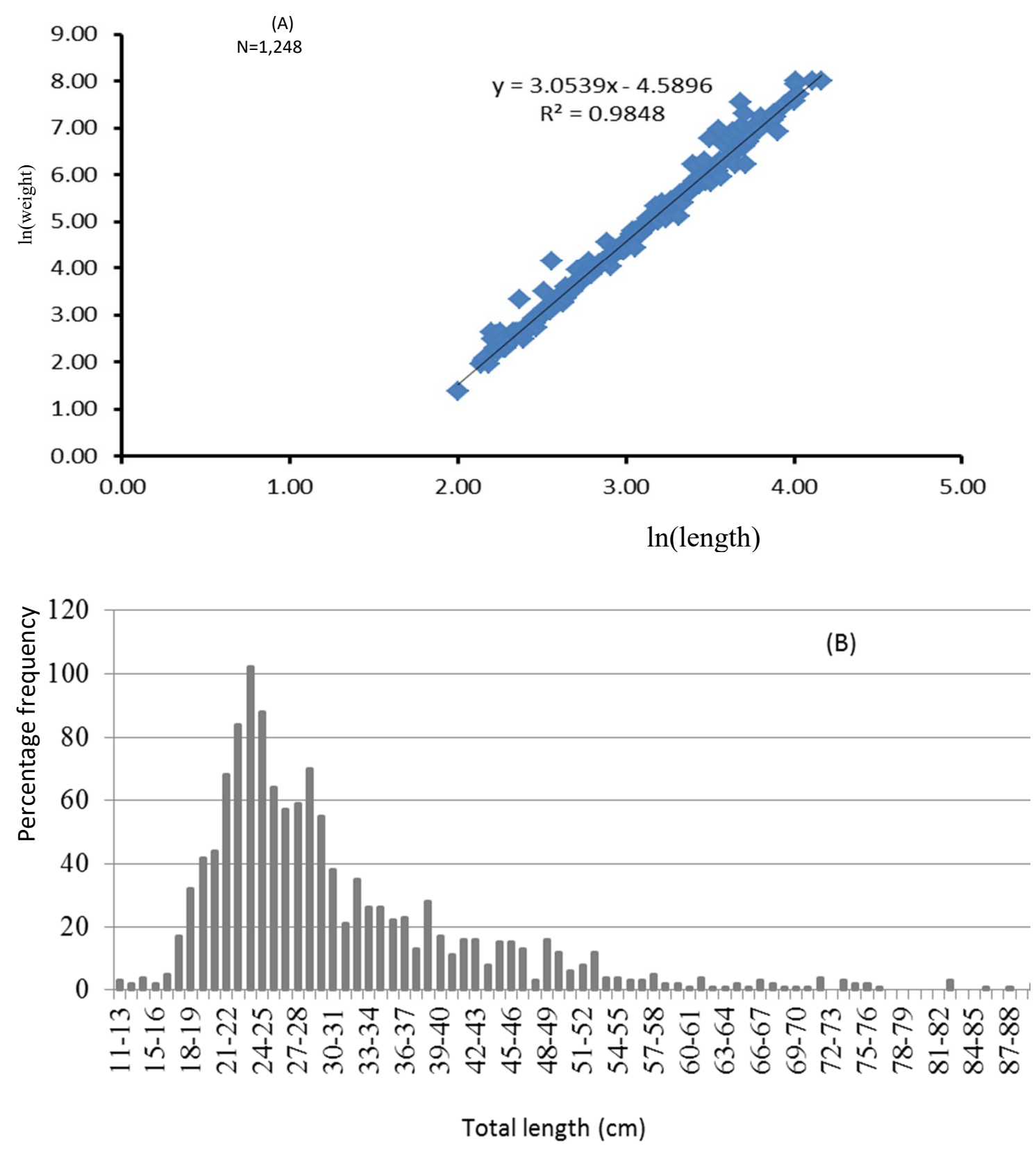

Figure 3. (A)The relationship between the natural logarithm of the total weight $(\mathrm{kg})$ and the natural logarithm of length $(\mathrm{cm})(B)$ Length frequency distribution from experimental gillnets for Lates niloticus upper Victoria Nile.

The length at first maturity $\mathrm{L}_{50}$ of the Nile perch for males and females recorded at $30.3 \mathrm{~cm}$ TL and $40 \mathrm{cmTL}$ respectively. The size structure for the whole sampling recorded almost $80 \%$ of the length class below the size at first maturity (Figures $3 \mathrm{~b}$ and 4 ). 


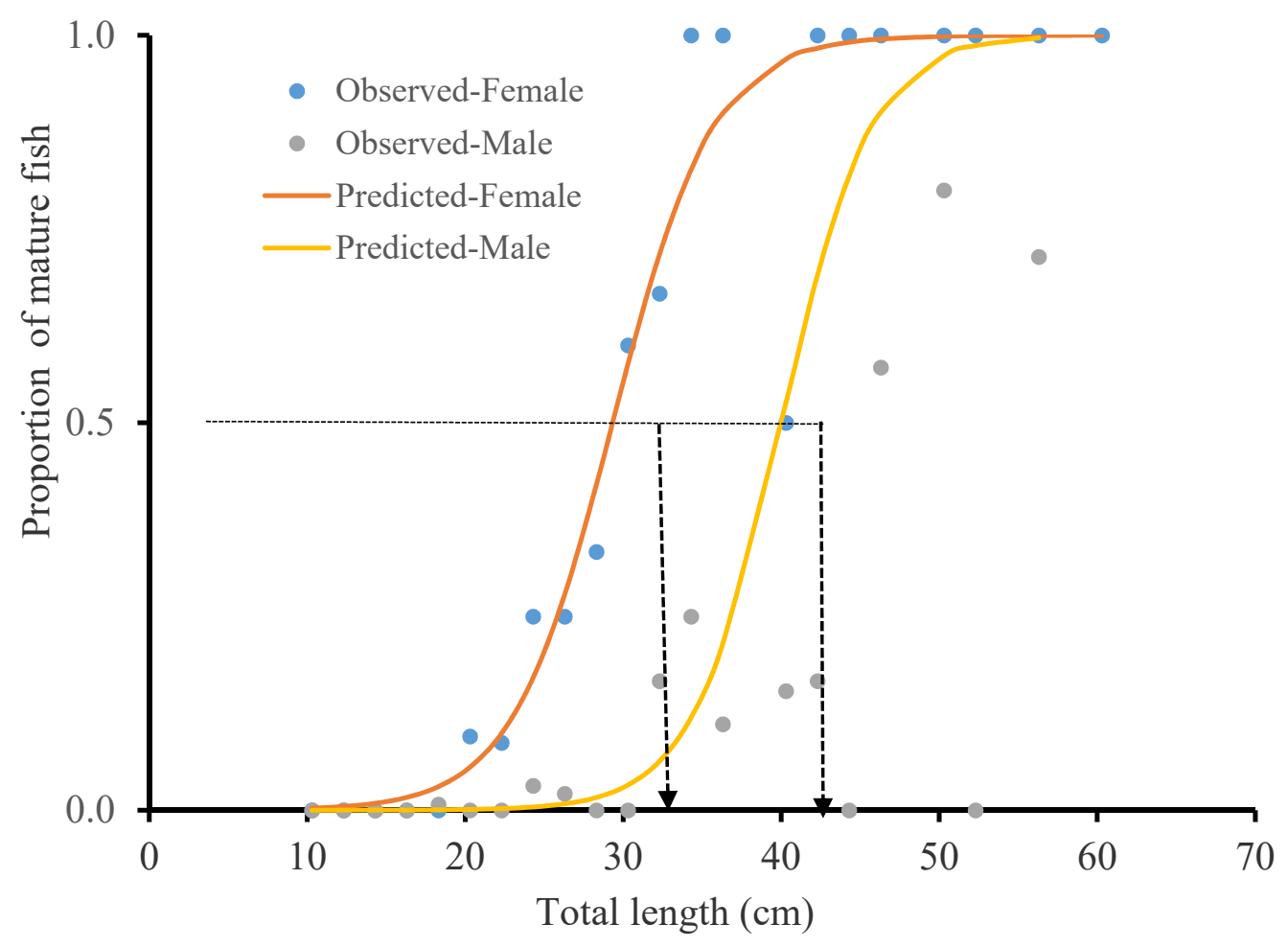

Figure 4: Maturity proportions $\mathrm{L}_{50}$ for Males and Females for Lates niloticus sampled from UVN waters during period of 2008-2018. Ogives is fitted to estimate length at maturity L50 in females and males represented by dotted lines

The growth parameters for the Nile perch recorded $\mathrm{L}_{\infty}$ of $93.45 \mathrm{~cm}$ (TL) and $\mathrm{K}=0.46$ per year. $t_{0}$ value was calculated by equation of Pauly as $t_{0}=-0.89747$ per year. $R_{n}$ (goodness of fist) was 0.2220 with ELEFAN-1 method. The length converted catch analysis VBGF growth parameters recorded ( $\mathrm{L}_{\infty}$ of $93.45 \mathrm{~cm}(\mathrm{TL})$ and $\mathrm{K}=0.46$ per year). The length frequency data of Nile perch was aggregated at $t_{\max }=7.4$ years as the maximum age for the species recorded for the whole period of sampling. Meanwhile length at birth was recorded at $t_{0}=-0.89747$ years.

The estimation of the mortality parameters of $Z=1.85$ per year of the total mortality $(Z)$ estimates and it was estimated at $95 \%$ confidence interval $(C L=0.76-2.93)$ (Figure 7). The value of natural mortality $(M)$ was calculated as $\mathrm{M}=0.76$ per year using riverine surface temperature of (RST) $26^{\circ} \mathrm{C}$. Thus the fishing mortality was calculated as $\mathrm{F}=\mathrm{Z}-\mathrm{M}=1.09$ per year and exploitation ratio (E) was selected from $\mathrm{F} / \mathrm{Z}=0.59, \mathrm{M} / \mathrm{k}=1.7174$ and $\mathrm{Lc} / \mathrm{L}_{\infty}$ was 0.050 . (Figure $5 \mathrm{a}$ and $\mathrm{b})$.

The growth performances indices for the asymptotic length $\left(\mathrm{L}_{\infty}\right)$ and asymptotic weight $\left(\mathrm{W}_{\infty}\right)$ were $\boldsymbol{\emptyset}=2.090$ and $\boldsymbol{\emptyset}=3.604$ per year respectively. There were two peaks recruitment period, a minor in March and a major in August, accounting for $12.8 \%$ and 26.3\% respectively. Beverton and Holt's relative yield-per-recruit model indicted the sustainable yield indices at 0.278 for optimum sustainable yield $\left(E_{0.5}\right), 0.421$ for maximum sustainable yield $\left(E_{\max }\right)$ and 0.355 for economic yield $\left(E_{0.1}\right)$ (Figures $5 \mathrm{c}$, d, Figure 6 ). 

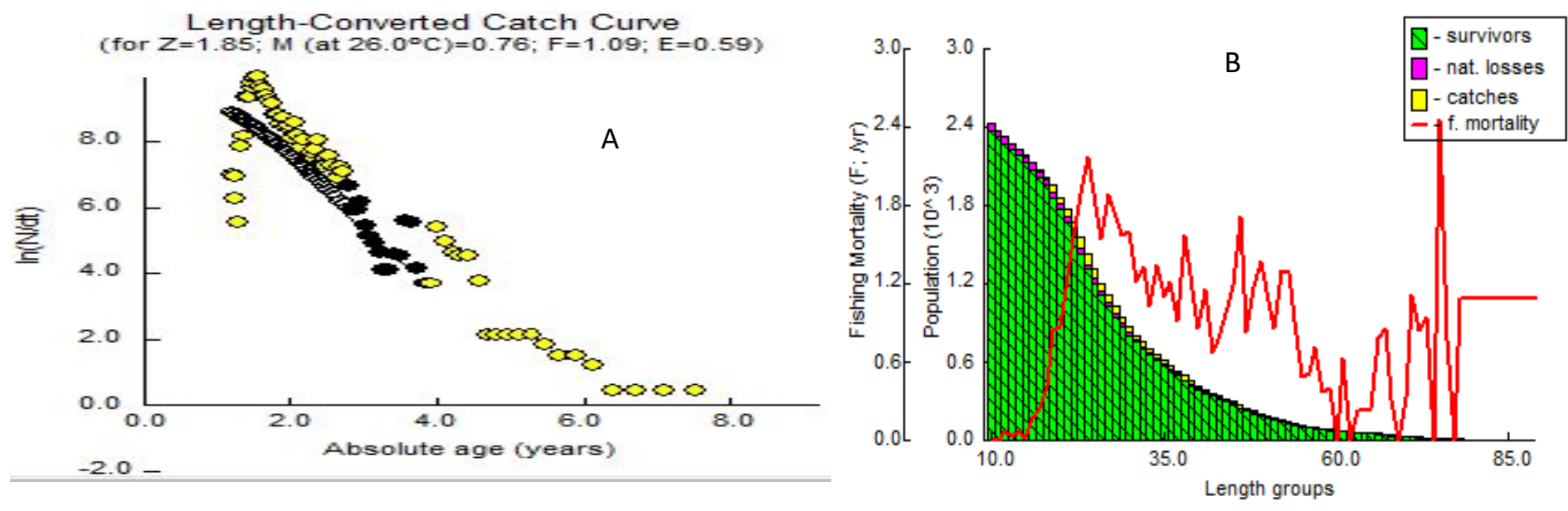

Enter the

coefficients of the

length-weight

relationship $(W=$

$\left.a L^{\wedge} b\right]$ :

a: $\quad 0.0102$

b: $\quad \longdiv { 3 . 0 5 3 9 }$

- Dther Parameters

M. $\quad 0.76$

Fr. $\quad 1.09$

Loo: $\quad \longdiv { 9 3 . 4 5 }$

K: $\quad \longdiv { 0 . 4 6 }$

+Groups: 11
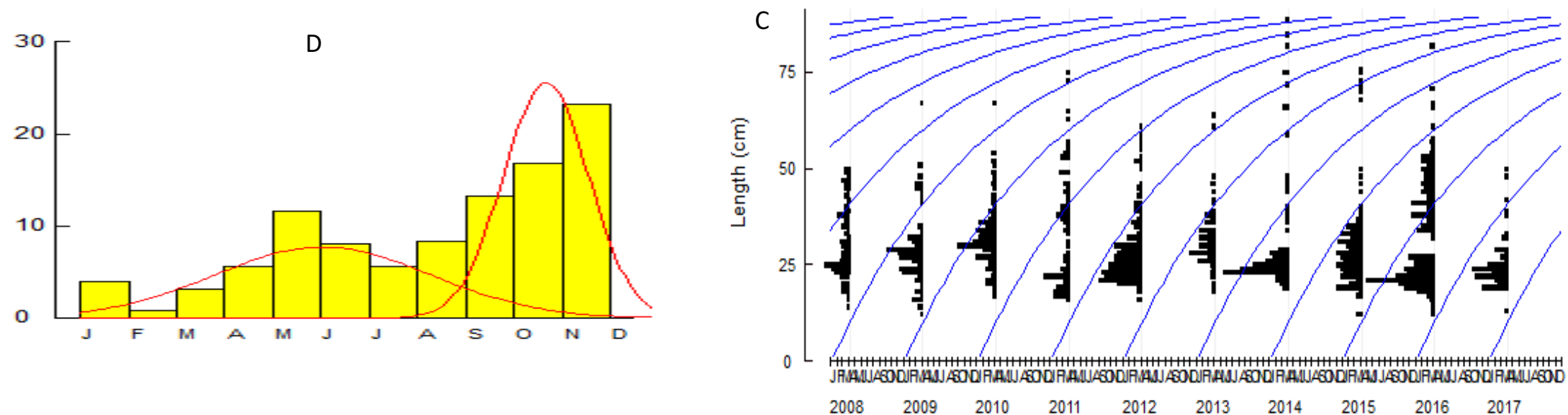

Figure 5: A-Growth parameters, B-Fishing mortality, C- von Bertalanffy growth function and length frequency for Lates niloticus ,D-Total length, von Bertalanffy growth curve for Lates niloticus. 


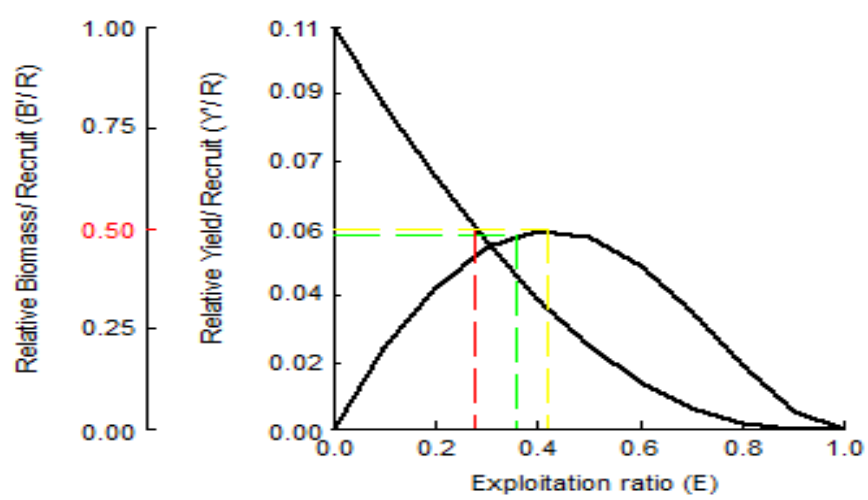

Figure 6. Beverton \& Holt's relative yield per recruit and average biomass per recruit models, showing levels of yield indices: $E_{0.5}-\mathrm{optimum}$ sustainable yield, $\mathrm{E}_{0.1}$ — maximum economic yield and $\mathrm{E}_{\max }$ - maximum sustainable yield

Table 1. Comparison of mortality parameters from UVN (2008-2018) with those from other areas.

\begin{tabular}{|c|c|c|c|c|c|c|c|c|c|c|c|}
\hline Source & Areas & $\mathrm{L}_{\infty}$ & $\mathrm{K}$ & $\mathrm{Z}$ & $\mathrm{M}$ & $\mathrm{F}$ & $\mathrm{E}$ & tmax & $\varnothing \mathrm{L}$ & L50 Male & L50 Female \\
\hline Current study & Current study & 93.45 & 0.446 & 1.85 & 0.79 & 1.09 & 0.59 & 7.4 & 3.604 & 30.3 & 40.0 \\
\hline Rabuor and Manyala, 1990 & Winamu Gulf, Lake Victoria 1990 & 205 & 0.19 & 4.725 & 0.34 & 4.385 & 0.928 & & & & \\
\hline Njiru et al.2008 (1998-00) & Lake Victoria Kenya & 204 & 0.21 & 2.92 & 1.50 & 1.42 & 0.80 & 14 & & 60 & 62 \\
\hline Njiru et al.2008 (2004-2005) & Lake Victoria Kenya & 133 & 0.25 & 3.40 & 0.58 & 2.92 & 0.86 & 12 & & 54 & 50 \\
\hline Nkalubo PhD Thesis 2010 & Lake Victoria & 160 & 0.17 & & & & & 14 & & & \\
\hline Bassa S.,2000 & Lake Victoria & & & 1.65 & 0.81 & 0.84 & 0.95 & & & & \\
\hline Yongo et al.,2018 & Lake Victoria, Kenya & 124 & 0.22 & 0.96 & 0.42 & 0.54 & 0.57 & & 3.53 & & \\
\hline
\end{tabular}


Table 2. Length-weight relationship parameters of Nile perch

\begin{tabular}{|c|c|c|c|c|}
\hline Reference & Research areas & $\mathrm{a}$ & $\mathrm{B}$ & $\mathrm{R} 2$ \\
\hline Current study & Current study Upper Victoria Nile (UVN) 2008-2018 & 0.0102 & 3.0538 & 0.984 \\
\hline Witte and Densen 1995: EAFFRO 1973-1975 & Tanzania part of Lake Victoria & 0.0066 & 3.155 & \\
\hline Witte and Densen 1995: HEST Team, 1988-1990 & Mwanza Gulf and Speke Gulf lake Victoria & 0.696 & 2.09 & \\
\hline Bassa S. 2011 & $\begin{array}{l}\text { The effect of hook and size on the catch rate and size of the Nile } \\
\text { perch in the Napoleon Gulf Lake Victoria, Uganda. }\end{array}$ & 0.0058 & 3.2005 & 0.9532 \\
\hline Akumu J. 1999 & $\begin{array}{l}\text { Spatial and Temporal Distribution on Fish stocks in the Napoleon } \\
\text { Gulf of Lake Victoria }\end{array}$ & 0.0027 & 2.97 & 0.95 \\
\hline Nkalubo 2010 & $\begin{array}{l}\text { Life History traits and growth of Nile perch in Lake Victoria, } \\
\text { Uganda: Implications for Management fishery. }\end{array}$ & 0.0072 & 3.132 & 0.9900 \\
\hline Yongo and Outa 2016 & Lake Victoria, Kenya & 0.0104 & 3.641 & 0.981 \\
\hline Ogutu-Ohwayo 1999 & Lake Kyoga & 0.0104 & 3.03 & 0.966 \\
\hline
\end{tabular}


Eleven (11) food types recorded from the gut contents of the Nile perch in the UVN. These included; Fish remains, Caridina nilotica, Lates niloticus, haplochromines, Ratrineobola argentae, Hydrocinus, Povilla, Chironmids, Tricoptera, Insect remains and Barbus species. The juveniles ranging from 7.4-18.5 cm TL the highest percentage fed on Caridina nilotica, Rastrineobola argentae and fish remains.

The Chi-square $\left(\mathrm{X}^{2}\right)$ test was used to tests for significance of differences in the diet for the fishes in the length range of 7.4-18.5 cm TL recorded:-

Ln, $\mathrm{n}=2$ (X2=000; $\mathrm{df}=1: \mathrm{P}>0.05)$, Rastrineobola argentae, $\mathrm{n}=94(\mathrm{X} 2=14.574 ; \mathrm{df}=11: \mathrm{P}<0.05)$, Haplochromines, $\mathrm{n}=60 \quad(\mathrm{X} 2=150.467 ; \mathrm{df}=6: \mathrm{P}<0.05)$, Barbus $\mathrm{n}=2(\mathrm{X} 2=0.000 ; \mathrm{df}=1 ; \mathrm{P}>0.05)$; Hydrocinus, $\quad \mathrm{n}=17 \quad(\mathrm{X} 2=8.154, \mathrm{df}=4 ; \mathrm{P}>0.05) ; \quad$ Fish remains, $\mathrm{n}=78$ $(\mathrm{X} 2=85.897 ; \mathrm{df}=7: \mathrm{P}<0.05) ;$ Povilla $\mathrm{n}=4 \quad(\mathrm{X} 2=0.000 ; \mathrm{df}=3: \mathrm{P}>0.05)$; Caridina nilotica $\mathrm{n}=157$ $(\mathrm{X} 2=429.339 ; \mathrm{df}=16: \mathrm{P}<0.05)$; Chironomid larvae $\mathrm{n}=9 \quad(\mathrm{X} 2=0.000 ; \mathrm{df}=2: \mathrm{P}>0.05)$; Tricoptera $\mathrm{n}=3(\mathrm{X} 2=0.333 ; \mathrm{df}=1: \mathrm{P}>0.05)$; Insect remains, $\mathrm{n}=5(\mathrm{X} 2=1.6 ; \mathrm{df}=2: \mathrm{P}>0.5)$.

Fishes ranging 19.0-64.0 $\mathrm{cm}$ TL, the chi-square test recorded:- $\mathrm{Ln}, \mathrm{n}=6$ $(\mathrm{X} 2=0.667: \mathrm{df}=1: \mathrm{P}>0.05) ; \quad$ Rastrineobola argentae, $\mathrm{n}=94(\mathrm{X} 2=57.731: \mathrm{df}=8: \mathrm{P}<0.05)$; Haplochromines, $\mathrm{n}=80(\mathrm{X} 2=198.4 ; \mathrm{df}=7: \mathrm{P}<0.05)$; Hydrocinus, $\mathrm{n}=6(\mathrm{X} 2=2.00 ; \mathrm{df}=3 ; \mathrm{P}>0.05)$; Fish remain, $\mathrm{n}=7(\mathrm{X} 2=83.254 ; \mathrm{df}=7: \mathrm{P}<0.05)$; Caridina nilotica, $\mathrm{n}=47(\mathrm{X} 2=41.0 ; \mathrm{df}=3: \mathrm{P}<0.05)$; Chiromids, $\mathrm{n}=6(\mathrm{X} 2=0.667 ; \mathrm{df}=3: \mathrm{P}>0.05)$.

One thousand and seven hundred sixty three $(1,763)$ Nile perch samples from UVN were collected. Females were 189, the males were 796 and the rest were immature constituting a ratio of 0.2:0.8. This ratio was significantly deviating from the hypothetical 1:1 females to males rate $(\mathrm{X} 2=1401.976 ; \mathrm{df}=5: \mathrm{P}<0.05)$.

\section{Discussion}

The Nile perch industry has created a remarkable economic benefit by transforming the artisanal industry into a multimillion dollar export industry of Nile fillets. In Kenya alone it is estimated to earn US \$3,330 million dollars per annum (Njiru et al. , 2008; Yongo, et al., 2018). The fishing industries along the shores of Lake Victoria have led to increased exploitation of the Nile perch that has led to some fishers migrate to the riverine system including the upper Victoria Nile. The migration patterns of the fishers could have led to the Nile perch stock decline as observed in this study over time and space. Although, Nile perch has continued to show isometric growth in the Upper Victoria Nile like in other open waters, such as Lake Victoria and Kyoga (Rabour and Manyala, 1990; Ogutu-Ohwayo 1999; Njiru et al., 2008, OgutuOhwayo et al., 2013, NaFIRRI report 2019). There was a noted decline in Lo (length) of Lates niloticus from this study. We also noticed decline from studies done by other scientists on the same species on the Lake Victoria. For instance, Rabour and Manyala (1990) recorded a length of $205 \mathrm{~cm}$ TL, Nkalubo (2012) recorded $160 \mathrm{~cm}$ TL while Yongo et al., 2018 study recorded 124 $\mathrm{cm}$ TL (Table 2). The current study has indicated a record of $93.45 \mathrm{~cm}$ TL and low value the length at first maturity in the upper Victoria Nile. Similarly, a decrease in Lo has led in low catches of the Nile perch thus fishers harvest the majority below slot size of 50-85 cm TL, as indicated in the length frequency distribution (Njiru et al., 2008, Yongo et al., 2018). The reported fish below and above the slot size has continued being caught and processed, thereby confirming the slot size is hardly adhered to by both the fishers and the processors on Lake Victoria systems and the same to the upper Victoria Nile. The reductions in the sizes of Lates niloticus are attributed by the illegal gears and methods used in the Nile perch fishery (Yongo et al., 2017, 2018, Nkalubo 2012). The Fisher folk in lakes Victoria and Kyoga have increasingly 
abandoned large-meshed gillnets in favour of small hooks on long lines (Mkumbo and Marshall, 2015, Yongo et al., 2018), which largely targets small size Nile perch. Besides that, the fishers use other illegal gears such as the basket traps, small sized gillnets, boat seines and cast nets that catches small Nile perch from the Upper Victoria Nile. The availability of Nile perch $<50 \mathrm{~cm}$ TL from the sampled data confirms an intensive illegal fishery in the upper Nile that created an impact on the stock sizes of the Nile perch.

The estimated instantaneous rate of total mortality $\left(\mathrm{Z}=1.85 \mathrm{yr}^{-1}\right)$ instantaneous rate of fishing mortality $\left(\mathrm{F}=1.09 \mathrm{yr}^{-1}\right)$ and instantaneous natural mortality $\left(\mathrm{M}=0.79 \mathrm{yr}^{-1}\right)$ obtained in this study are higher than the values reported by Yongo et al., 2018 and Bassa 2000 for the Nile perch in Lake Victoria, Uganda and Kenya respectively (Table 1). The implication is that Nile perch die more due to human exploitation than natural death. With an estimated $\mathrm{E}=0.59$ during the study, one can infer that the stock of Nile perch of the upper Victoria Nile in the Bujagali stretch, is probably experiencing excessive fishing pressure. This is based on the assumption that in an optimally exploited stock, natural and fishing mortalities should be equal or $\mathrm{E}=\mathrm{F} / \mathrm{Z}=0.5$ (Abowei et al., 2010, Sparre and Venema, 1998). The maximum exploitation rate ( $\left.\mathrm{E}_{\max }\right)$, which gives maximum relatively yield-recruit is estimated by Yongo et al., 2018 at 0.5 greatly differs from exploitation rate $(0.421)$ estimated in this study. This further suggests that the population stocks is probably over fished both in terms of yield - per recruit and biomass-per -recruit as suggested by Sparre and Venema 1998 adopted by Abowei et al., 2010. This implies that the level giving maximum sustainable yield has been overshot, thus driving the Nile perch stock down (Abowei et al., 2018).

The range of $\mathrm{M} / \mathrm{K}$ ratio 1.7174 is below the Beverton and Holt (1966) range of 1.0-2.5 for fishing indicating a poor environment state. The $\mathrm{M} / \mathrm{K}$ ratio is an indirect method used in research to examine the accuracy of growth parameters and is supposed to be constant for group species or closely related families or taxa (Abowei et al., 2010).

The recruitment patterns established in this study revealed an all year round recruitment with two peak (one major and the other secondary). The major was observed in the month of March and a major one in August that accounted for $12.8 \%$ and $26.3 \%$. This observation conforms to the assertions of Pauly (1983) and Abowei et al., 2010 that characteristics of most tropical fish stock with seasonal associations. The all year round recruitment is most likely to compensate for the high mortality rates, of the Nile perch as observed from the results of this study.

Nile perch has continued to predominantly feed on the protein-rich diet Constituting of fish including its own young ones (Ogutu-Ohwayo, 1990; Rabour et al., 2003; Njiru et al., 2008; Yongo et al., 2018). The prey type of the species could have led to improved growth performance and maintenance of the large specimens.

The rate of increasing mortality rates and reduction in growth parameters of the Nile perch signifies a decline in the stock level at the UVN. To keep the UVN fishing at a sustainable level will need sustainable yield and avoid overfishing problems. Thus, managing the Nile perch fishery in the UVN, need strict adherence to the slot size of 50-85 cm TL, restrictions on illegal gears, enforcement and fisheries control and surveillance working in tandem with the riparian communities.

\section{Acknowledgement}

We thank the National Fisheries Resources Research Institute, Jinja, staff who were involved in the data collection for the study. We also thank Bujagali Energy Limited for funding the study. 


\section{References}

A., and P.T. Ramesh 2017.Stock assessment of Indian Scad, Decapterus Resselli in Pakistani Marine Waters and its Impact on the National economy. Fisheries and Aquaculture journal. Doi: 10.4172/2150-3508.1000200.

Abowei, J.F.N, George A.D.I and O.A. Davies 2010. Mortality, exploitation rate and recruitment Pattern of Callinectes amnicola (De Rochebrune, 1883) from Okpoka, Creek, Niger Delta, Nigeria. Asian journal of agricultural Sciences 2(1): 27-34 ISSN: 2041-3890.

Akumu J. 1999. Spatial and Temporal Distribution on Fish stocks in the Napoleon Gulf of Lake Victoria. MSc. Thesis, Makerere University, Uganda.

Anderson A.M. 1960. Further observations concerning the proposed introduction of the Nile perch into Lake Victoria. East African Agricultural and forestry journal.

Aruho C., Ddungu R., Nkalubo W., Ondhoro C.C. Bugenyi F., and J. Rutaisire, 2018.

Balirwa J.S., C. A. Chapman, L. J. Chapman, K. Geheb, R. Lowe-McConnell, O. Seehausen , J. Wanink, R. Welcomme O.F. Witte 2000.The Role of Conservation in Biodiversity and Fisheries Sustainability in the Lake Victoria Basin. Conference proceedings of 2000, Uganda, Jinja.

Balirwa S.J. 2007. Ecological, environmental and socio economic aspects of the Lake

Bassa S. 2000. Distribution and abundance of Nile perch (Lates niloticus) and Nile tilapia (Oreochromis niloticus) in Lake Victoria Uganda. Fisheries Resources Research Institute. United Nations University Iceland.

Bassa S. Getabu, D.O. Owiti, A.M. Taabu, E. Ogello, N.E. Orina, L.I. Muhoozi, R. Olwa, H. Nakiyende, D. Mbabazi., E.K. Muhumuza, J.S.Balirwa and W. Nkalubo, 2019. Assessment of the Ecosystem integrity of the Upper Victoria Nile (UVN), East Africa based on Habitat and Fish species biotic indices. Uganda Journal of Agricultural Sciences, 19 (1), 1-17, Doi: http://www.ajol.info/index.php/ujas.

Bassa S., D.O. Owiti, A. Getabu, H. Nakiyende, W. Nkalubo, J.S. Balirwa, V. Natugonza, D. Mbabazi and A.M. Taabu. 2018. Effects of exploitation pressures and river damming on the population structure of Elephant snout fish (Mormyrus kannume) Forsskal 1775: A case study on the upper Victoria Nile, East Africa. Uganda Journal of Agricultural Sciences, Volume 18 Number 1 (2018) pp. 1 - 17.

Bassa, S. 2011. The effect of hook size on the Catch rate and size of the Nile perch Lates niloticus (LINNE) fishery in the Napoleon Gulf, Lake Victoria Uganda (MSc thesis Islamic University, Uganda).

Beverton, R. J. H., \& Holt, S. J. 1966. Manual of methods for fish stock assessment. Part II. Tables of yield function. FAO Fish. Biol. Techn. Paper. 38, 10 (Ver. 1): 1-67.

Brown-Peterson N.J., Wysanski D.M. Saborido-rey F., Maceoic B., LOWERRE-Babieri S.K 2011. A standardised terminology for describing reproductive development in fishes. Mar Coast Fish: 391) 52-70. https://doi.org/10.1080/19425120.2011.555724.

Froese R. 2006. Cube law, condition factor and weight-length relationships; history metaanalysis and recommendation J. App in Inchcthyol.

Gayanalo, F.C. and Pauly, D., (1997) The FAO ICLARM Stock assessment Tools (FISAT) Reference Manual. FAO Computer Information Series. (Fisheries), 8, 262p.

Kalhoro, T. M., Yongtong, M., Kalhoro, M.A., Hussain, S.S.B., Mahmood, M.A., Muhammad, LVFO, (2007b). Standard Operating Procedures SOPs for Frame Assessment Surveys on Lake Victoria. LVFO Standard Operating Procedures No. 2, LVFO, Jinja.

Mkumbo, O. C., \& Marshall, B. E. 2015. The Nile perch fishery of Lake Victoria: Current status and management challenges. Fisheries Management and Ecology, 22, 56-63. https://doi.org/10.1111/fme.12084. 
NaFIRRI report (2018). Aquatic and Fisheries survey of the Upper Victoria Nile. A report prepared for AES Nile Power Bujagali Hydropower Project.

Njiru. M., Owili. M.O., T. Jembe, C. Ngugi 2008.Increasing dominance of Nile tilapia, Oreochromis niloticus (L) in Lake Victoria, Kenya: Consequences for the Nile perch Lates niloticus (L) fishery. Aquatic Ecosystem Health and Management. Doi: 10.1080/14649870187809.

Nkalubo, W. 2012. Life History traits and growth of Nile perch, Lates niloticus (L), in Lake Victoria, Uganda: Implications for management of the fishery. PhD thesis (Makerere University).

Nkalubo, W. Balirwa, J. Bassa, S. Muhumuza, E. Nsega, M. and Mangeni, R. 2018. Fish breeding areas as a management tool for resources in Lake Victoria, East Africa. African journal of Tropical hydrobiology and Fisheries 16:1-9 (2018).Lake Victoria Fisheries Organization.

Ogutu Ohwayo, R., Odongkara, K., Okello, W, Mbabazi, D, Wandera, S.B., Ndawula, L.M., and V. Natugonza, 2013. Variations and changes in habitat, productivity, composition of aquatic biota and fisheries of the Kyoga lake system: lessons for management. African journal of Aquatic science.ISSN1608-5914.

Ogutu-Ohwayo R. 1999. Deterioration in length-weight relationships of Nile perch, Lates niloticus (L.) in lakes Victoria, Kyoga and Nabugabo. Hydrobiologia 403, 81-6.

Ogutu-Ohwayo, R. 1990. Changes in the prey ingested and the variations in the Nile perch and other fish stocks of Lake Kyoga and the northern waters of Lake Victoria (Uganda). Journal of Fish Biology. 37, 55-63. https:/ /doi.org/10.1111/j.1095-8649.1990.tb05926.x.

Okaranon J.O., Muhoozi L.I. and Bassa S. 1999. Current state of the Fish Stocks of Lake Victoria (Uganda). In: D. Tweddle and I.G. Cowx: Report on fourth FIDAWOG workshop for the Lake Fisheries Research Project (Phase II), held at Kisumu (Kenya), 16th - 20 th August 1999. Technical Document No. 5, LVFRP/TECH/99/05.30-39.

Optimising selection of sexually mature Barbus altinialis for induced spawning determination of size at sexual maturity of population from Lake Edward and upper Victoria Nile in Uganda. Fisheries and Aquatic Sciences https://doi.org/10.1186s41240-018-01.

Pauly, D., \& Soriano, M. L. 1986. Some practical extensions to Beverton and Holt's relative yield-per-recruit model. In J. L. Maclean, L. B. Dizon, \& L. V. Hosillo (Eds.), The first Asian fisheries forum (pp. 491-496). Manila, Philippines: Asian Fisheries Society.

Pauly, D., 1983. Some simple methods for the assessment of tropical fish stocks. FAO Fish Technical papers, 234. 52p.

Pauly, D., and D. Morgan 1987. Length-based methods in fisheries research, ICLARM conference Proceedings 13, International Centre for living Aquatic Resources Management, Manila and Kuwit Institute for Scientific Research.

Pringle R. M. 2005. The origin of the Nile perch in Lake Victoria. Bioscience journal, vol.55, no.9, page $780-787$.

Rabour C.O. and J.O. Manyala 1990. Multi-gear fishery of the Nile perch (Lates niloticus) in the Winam Gulf of Lake Victoria: with special reference to mortality, selection and catch/effort data. Kenya Marine and Fisheries Research Institute Sangoro Riverine laboratory. World Fish Centre Quarterly, 26(4), 8-12.

Rabour, C.O., Gichuki, J. and Moreau, J. 2003. Growth, mortality and recruitment of Nile Perch Latesniloticus (L. Centropomidae) in the Nyanza Gulf of Lake Victoria: and evaluation update. Naga 26(4): 8-12.

Sitoki, L., Gichuki, J., Ezekiel, C., Wanda, F., Mkumbo, O. and Marshall B. E. 2010. The Environmental of Lake Victoria (East Africa) current status and history changes. Internat. Rev. Hydrobiol. 95. 2010.3.209-223. 
Sparre, P., and Venema, S., C., 1998. Introduction to tropical fish stock assessment manual. Part 1 Manual FAO Technical paper 306/1 Rev.2. Rome, FAO. 209-210. M-43.ISBN-92-5103996-8.

Victoria's introduced Nile perch fishery in relation to the native fisheries and the species culture potential: lessons to learn. The African Journal of ecology 45, 120-129. Blackwell publishing Ltd.

Welcomme, R., Coxw G.I., Coates D., Bene C., Funge-Smith S., Halls A., Lorenzen K., (2010). Inland capture fisheries. Phil. Trans. R. Soc. B. 365, 2881-2896, Doi:10.1098/rstb.2010.0168. Yongo E., Otieon, O.H., Agembe S., 2018. Growth, mortality and recruitment of Nile perch (Lates niloticus) in Lake Victoria Kenya. Lakes and Reservoirs Research and Management. DOI: $10.1111 \mathrm{ke} 12203$. 